\title{
Universities responding to the call for sustainability : A typology of sustainability centres
}

\section{Soini, Katriina}

2018-01-01

Soini , K , Jurgilevich , A , Pietikainen , J \& Korhonen-Kurki , K 2018 , ' Universities responding to the call for sustainability : A typology of sustainability centres ', Journal of Cleaner Production , vol. 170 , pp. 1423-1432 . https://doi.org/10.1016/j.jclepro.2017.08.228

http://hdl.handle.net/10138/325657

https://doi.org/10.1016/j.jclepro.2017.08.228

cc_by_nc_nd

acceptedVersion

Downloaded from Helda, University of Helsinki institutional repository.

This is an electronic reprint of the original article.

This reprint may differ from the original in pagination and typographic detail.

Please cite the original version. 
Title page

Title:

Universities responding to the call for sustainability: A typology of sustainability centres

Authors:

Corresponding author

Katriina Soini, PhD., Adjunct Professor

Sustainablity Science Fellow

University of Helsinki

Centre for Environment, HENVI

Viikinkaari 2a

00014 University of Helsinki

Katriina.soini@helsinki.fi

Alexandra Jurgilevich, M.Arts

PhD researcher

University of Helsinki

Department of Environmental Sciences

Viikinkaari 2a

00014 University of Helsinki

Janna Pietikäinen, PhD.

University lecturer

University of Helsinki

Centre for Environment, HENVI

Viikinkaari 2a

00014 University of Helsinki

Kaisa Korhonen-Kurki, PhD., Adjunct Professor

Research Co-ordinator

University of Helsinki

Centre for Environment, HENVI

Viikinkaari 2a

00014 University of Helsinki

Corresponding author

Katriina Soini

Katriina.soini@helsinki.fi 


\begin{abstract}
Universities worldwide are experiencing a growing trend to respond to the need for sustainability. Sustainability centres are one key aspect in the sustainability transitions of universities. Until currently, these centres have been relatively neglected by research. This exploratory study makes a solid contribution to the scholarship and understanding of the various means by which universities are responding to the societal challenge of sustainability by analysing a sample of 44 sustainability centres across the world to increase understanding of the characteristics and roles of these centres in contributing to sustainability. Furthermore, the study identifies four types of centres differing in their goals, objects, scope and scale of research, knowledge production and outreach activities. The typology of the centres can be applied for example when new centres are established or when centres identify or redefine their profiles. The authors suggest further research concerning sustainability centres, given their central role as nodes of sustainability research, education and co-creation in sustainability transformation.
\end{abstract}



of sustainability (Beynaghi et al. 2016; Ferrer-Balas et al. 2010, Waas et al. 2010). Sustainability has been seen not only as a component of education, research and innovation, but also as a social learning process within and beyond academia (Barth \& Michelsen 2013; Ferrer-Balas et al. 2009; König 2015). As an indication of the increased focus on sustainability, hundreds of universities have joined the Sustainable Development Solutions Network supported by the United Nations (UN), or other networks related to sustainability (e.g. the International Sustainable Campus Network (ISCN), the Association for the Advancement of Sustainability in Higher Education (AASHE) in the USA, the Environmental Association for Universities and Colleges (EAUC) in the UK). Additionally, a number of university-based centres or institutes focusing on sustainability have been established. In a worldwide survey addressed to universities, Lozano et al. (2015) have found that sustainability centres are one of the key activities in the sustainability transitions of universities. In this paper, we aim to characterise and examine university-based research centres and institutes that use sustainability and/or sustainable development concepts as the main framework of their research and outreach activities.

The evolution of university-based sustainability centres can be seen as part of a broader process of integrating sustainability into universities' research and curricula. Beynaghi et al. (2016) have shown that sustainable development in the 1980s promoted an initial "acknowledgement" response in certain institutes, particularly in the visions of frontrunner institutions. Focus was placed on engineering and physical sciences, and on efforts to address environmental issues through technological development. During the second phase, in the 1990s, sustainable development entered the curricula and university activities more broadly through public commitment to sustainability policies (see also Lozano et al. 2013). In the third phase, since 2000 onwards, sustainable development has been integrated more deeply into the structures and missions of universities. Technology transfer, entrepreneurialism, societal interventions and the co-creation of tools and experiments to drive societal transformations towards sustainability have become more and more significant areas of activity in universities (Trencher et al. 2013). These new roles adopted by universities have been called the sustainability transition or transformation of universities (Baker-Shelley et al. 2017, Stephen \& Graham 2010), the third revolution of universities (Dedeurwaerdere 2013), or, when contributing to societal change, the "fourth mission" of universities (Trencher et al. 2013).

As part of this latest trend, certain universities have aligned their activities with the principles of sustainability science (e.g. Barth \& Michelsen 2013; König 2015; Wiek et al. 2012). Sustainability science, as an emerging field of research and discipline, aims not only to increase understanding of the complex socialecological systems (Kates et al. 2001), but also to link this knowledge to action (Miller 2014). This means crossing disciplinary and sectoral boundaries: conducting research not only for society, but also with society by involving non-academic stakeholders in the research process, and fostering transformative learning and social change (Spangenberg 2011).

The evolution of sustainability research and education can be seen as a response to the "sustainability call" expressed by international conventions related to sustainability and the environment, most recently by the UN Sustainable Development Goals and the Paris Climate Agreement in 2015. Yet, despite mutual benefits for both universities and society, and many successful examples, studies also document various internal and external challenges and constraints when organising multi-, and in particular, inter- or transdisciplinary sustainability research and education (see e.g. Beynaghi et al. 2016; Dedeurwaerdere 2013; Kueffer et al. 2012; Poteete et al. 2010; Redman 2014; Stephen \& Graham 2010; Trencher et al. 2014; Zilahy and Huisingh 2009). We summarise these challenges as scientific, organisational, supportive, conceptual and 
ideological. First, sustainability research and education are distinct from the dominating monodisciplinary collaboration. Second, academic research, education and the administration have been strongly disciplinary-based. New types of organisational structure, culture and communication practices are required to cross disciplinary boundaries and to increase the feasibility of research collaboration with nonacademic partners. Third, current rewarding and funding systems within the academia do not necessarily support inter- or transdisciplinary sustainability research and education. Finally, the conceptual vagueness of sustainability along with varying and conflicting aims and goals related to it, may cause problems in interand transdisciplinary collaboration and communication.

Sustainability centres have presumably developed various types of organisational structures along with scientific approaches to meet these challenges. Following the socio-technological transition framework (Geels 2002; Geels \& Schot 2007), applied in the university context by Stephens and Graham (2010), we suggest that sustainability centres could be considered "niches" within universities when trying to create scientific and organisational conditions for inter- and transdisciplinary sustainability research and education. Niches are usually developed by small networks of dedicated actors and built up by an internal momentum through learning, performance improvements and support from powerful groups. Their evolution is influenced by the socio-technical landscape, the wider socio-political context from market to national and international policy, and from demography to technology. The dominant practices mentioned above represent regimes that can contribute to or detract from a transition towards sustainability within universities. Destabilisation of the regime due to, for example, pressure in the landscape (in the case of universities new societal requests for science or funding availability) may create windows of opportunity for niche innovations (Geels, 2002).

A number of studies have explored sustainability transitions (e.g. Ferrer-Balas et al. 2008; Ferrer-Balas et al. 2009; Huge et al. 2016; Stephen \& Graham 2010) within universities, but none have focused on sustainability centres. By analysing 44 university-based sustainability centres our exploratory study provides insights on what kinds of organisations these centres are and how their research programmes and activities respond to sustainability challenges, and finally, proposes a typology of the centres. In the next chapter, a framework for analysing various approaches for responding to sustainability challenges is introduced. The data and methodology are presented in Chapter 3. Chapter 4 characterises the centres using information extracted from their websites and a survey, and proceeds with introducing the typology. Chapter 5 discusses how the centres differ in their evolution and sustainability orientations, and Chapter 6 draws up conclusions on how the centres respond to the call for sustainability and provides recommendations for further studies.

\section{Sustainability centres contributing to sustainability}

When exploring the role of sustainability centres in contributing to sustainability it is crucial to ask how the centres can potentially work for sustainability and how they legitimise their work. This is particularly important to reflect upon, as sustainability is not only an academic, but also a political concept, and a goal that provides a special feature to the activities of the centres. Moreover, given the conceptual and theoretical broadness and vagueness of sustainability, the centres apply varying approaches, with implications to knowledge production and science-related activities. To understand different characteristics of and functions performed by sustainability centres, we have appropriated a framework from Soini (2017). The framework was originally developed to present the key qualities of sustainability science, and to show how the produced knowledge is connected to the study object, goal in sustainability and methodologies of sustainability science. This appears in Figure 1 and is explained in detail in the following paragraphs. 
First, we assume that the centres have varying goals regarding sustainability. Different approaches pursuing development framework (see e.g. Chappin and Ligtyoet 2013; Feola 2015; Hopwood et al. 2005; Lonsdale et al. 2015; Markard et al. 2012; Mustelin and Handmer 2013; Redman 2014; Schulz \& Siriwardane 2015; Stirling 2014 exploring the differences between these approaches). These approaches are derived from various theories, for example resilience, transition, social practice, ecological modernisation or innovation theories, or their combinations. These theories offer differing ideas about human-environment relationships or social-ecological systems. They are also distinct in their normative aspect to change, for example, whether the goal is to maintain, return or transform the system or situation concerned. Moreover, they also differ in their response to change, i.e. whether adapting, mitigating or aiming at affecting the change pro-actively or changing the system fundamentally. Second, although the promotion of sustainability is the centres' general object of research, they may explore it through various perspectives (such as social, ecological, economic or cultural), spatial scales (from regional to global) or sectoral scopes.

Third, the goal and object of the research have, in turn, implications for the type and quality of knowledge produced. Academic research is typically motivated by a researcher's interest in increasing the academic knowledge of a given phenomenon. Obviously, a part of sustainability research is connected to this traditional research interest, producing descriptive analytical knowledge of human-environment interactions or social-ecological systems. The field of sustainability science may apply descriptive-analytical approaches, but in contrast to traditional science it also places efforts on using transformative approach and learning (Adomssent 2013; Barth \& Michelsen 2013; König 2015; Trencher et al. 2013; Wiek \& Lang 2016), aiming to produce socially robust knowledge regarding real-world problems (Nowotny et al. 2010; Wiek et al. 2012). Such knowledge is assumed to lead not only to the increased understanding of the given phenomena and practical solutions in society, but also to changes in the knowledge systems and values (Mezirow 1995; Sterling 2010; König 2015), and to social learning and actions (Lotz-Sisitska et al. 2015). Such transformative knowledge (Will \& Ryden 2015) is typically context-related and co-created by scientists, citizens and decision-makers.

Finally, various knowledge interests and knowledge types have implications for the methodologies and actions employed. Sustainability research has typically been multidisciplinary, bringing different disciplines together to understand or solve sustainability problems or to measure sustainability. While multidisciplinary sustainability research may be more thematically oriented, inter- and transdisciplinary approaches aim to increase and deepen this collaboration and even transcend the boundaries between various disciplines and academic and non-academic partners in the problem solving. Given that sustainability is not only an academic interest, but also a policy goal that universities address, collaboration with non-academic partners is natural, giving special attention to knowledge communication. This collaboration may take various forms ranging from the co-production of knowledge to the co-creation of measures that seek to transform society (Trencher et al. 2014a; 2014b).

\section{Data and methodology}

For the purposes of this paper, sustainability centres were defined as university-based research centres that use sustainability and/or sustainable development concepts as the main framework of their research and outreach activities. We acknowledge the existence of independent research institutes, think tanks and other types of sustainability research organisations, which do not, however, belong to the scope of this study. The initial search for the sustainability centres was performed using Google in the English and German languages with the keywords 'University' and 'sustainab* centre/research institute'. First, the search has been limited to university-based centres only, and therefore independent think tanks and research institutes were excluded from the study. Second, sustainability and/or sustainable development concepts had to be reflected in the name of the centre, as we were interested in centres that use these 
themes as the overarching framework for their research activities. We acknowledge certain limitations of Google use associated with personal browser settings, regional settings and a certain bias of the Google engine when retrieving search results according to a user's previous browsing history. This may affect search results for different users, and does not provide the basis for a completely replicable search. We also acknowledge the limitation of the languages used, and assume that more centres could have been retrieved with keyword searches in other languages. Our secondary search pool was the member directory of the International Sustainable Campus Network (ISCN). Finally, we have gone through the list of Universities committed to the Rio+20 Higher Education Sustainability Initiative. All searches have been performed until the results were exhausted, and were stopped at 44 centres from Europe, North America, New Zealand and Japan. The list of studied centres is presented in the supplementary material.

Two datasets were formed based on the searches. The first dataset consists of the website content of each selected centres based on the versions saved on 15 June 2016. An Excel table with predefined categories was used to collect information presented by the centres (see Table 1). This dataset was used for a descriptive analysis of the centres' main characteristics. The second dataset is based on the survey sent out to the selected 44 centres. The survey was administered over the period from November 3, 2015 to November 27, 2015, and sent to the leading research or administrative personnel (e.g. research directors, directors). The response rate was $36 \%$ (16 centres). The survey included open-ended and structured questions, and was used to explore more in-depth organisational matters and scientific approaches (see Table 1).

\subsection{Analysis}

First, descriptive analysis was conducted to describe the main characteristics of the centres based on website content and partially on the survey for the following categories: establishment, organisation, methodological approaches, and use of sustainability science (see section 4.1; Table 1). For organisation characteristics, two pre-identified categories were used: a network of researchers and an independent unit. In the case of a network of researchers, centres may or may not have physical headquarters, but do have a small administrative personnel, while most of the research personnel is affiliated with the faculties. Independent units on the contrary have physical headquarters, with affiliated administrative and research personnel. The following criteria were used separately or in combination, depending on data availability, to ascribe a centre to a certain type of organisation: research and administrative staff number, affiliation of research personnel (affiliated to the centre or to various faculties), physical address, funding and the history of establishment. In many cases, these categories were unclear, and personal judgement was used for the classification. The website dataset was also analysed in regards to the objectives, strategies and presented activities of outreach, i.e. services provided by the centres to local or global communities and organisations. All outreach activity types were examined and finally clustered as: 1 ) knowledge transfer; 2 ) establishing partnerships and co-production of knowledge; 3) promoting science-policy interface; 4) engaging local communities; 5) student-centred projects and 6) consultancy. Despite the data quantity and quality variability, all centres presented some form of outreach (Figure 2). Certain outreach activities may fall into several clusters, for example, student projects operating with local communities fall into two clusters.

Second, we have conducted a qualitative content analysis of the centres' approaches based on their website information, such as the centres' visions, missions, research approaches and themes (see Chapter 4.2). The quantity and quality of these data varied remarkably. The categorization of the findings was conducted in accordance with Figure 1, including the goal in sustainability, object of research, type of knowledge produced and methodologies and actions. The names for the types were derived from the goals in sustainability. 
Based particularly on the orientation of knowledge production and goal in sustainability, we finally (III) Building and maintaining resilience; (IV) Transforming society for sustainability. The types created through this process are ideal: a certain type is not necessarily meant to correspond with all of the attributes and categories associated with the type, but rather stress certain elements common to most cases of the given phenomena (Kluge 2000; Silsh and Finch 1997). The typology does not take into account the approaches of individual research projects, but is based on the overall approach of a centre.

It should be noted that the websites are considered a form of representation. They are means of communication and employ a certain style of language when constructing the identity and building the image of each centre. The website descriptions should not be considered as a literal reflection of the sustainability centre concerned. We assume that in reality certain statements are possibly exaggerated or that they do not accurately convey the most recent or relevant activities. Additionally, the information presented on the websites is fragmented and the data collected varied in quality. The survey was used to explore in-depth questions that could not be explored through the websites, such as challenges, enabling and hindering factors, history and development (see Table 1).

\section{Results}

\subsection{Establishment, organisation and activities}

Out of 44 centres, most ( 31 centres) have been established between 2006 and 2016 . Three centres were established before 2000. However, some centres have indicated that they have been established in the 1990s as centres, for example, for the environment, and have taken their current form with focus on sustainability later on in the 2000 s and 2010 s (see Table 2).

Based on the survey data gathered from 16 centers, we can distinguish two main enabling factors: 1) internal reasons of a university such as a window of opportunity for tightening the interdisciplinary collaboration in the university's re-structuring processes or 2) in a few cases external reasons such as strong societal need to collaborate with the university to achieve sustainable solutions. However, in most cases (13) individual university actors had a strong leadership in the establishment processes, which was often connected to the re-organisation of the university structures, strong research tradition in sustainability, societal needs and external funding. The external reasons refer to situations where a non-academic actor, such as a city, municipality, regional development agency or a private company or foundation, has actively promoted the establishment of the centre.

Based on website information we have broadly divided the organisational structure types into two categories: a network of researchers and independent units. With a network, we refer to centres that function as a platform for unifying researchers from different faculties and disciplines, providing space for inter- and transdisciplinary research. Such centres operate with the support of a small administrative staff. Under an independent unit, we identified centres that are established separately from the faculties, operating in their own premises and with their own administrative and affiliated research personnel. Out of 44 selected centres, 14 were classified as co-ordinated networks of researchers. In this case, researchers were usually based in the faculties and collaborate only through the research co-ordinated by the network. Twenty-eight centres were classified as independent university-based entities, usually called a research centre or institute. Many universities had a number of such centres, which were often grouped thematically. These centres can be a part of a faculty or cross-faculty institutions with their own director, administration and financies. Two of the centres worked as part of a consortium comprised of several universities or research institutes. 
According to the survey data, the advantages of acting as an independent unit were both scientific and organisational: being small, autonomous, dynamic and attractive in the field of sustainability research, but having the support of the university for funding, infrastructure and affiliations. The advantages of the networks were obviously related to the flexibility and freedom of an open network, as no special organisational or funding concerns were defined, thus facilitating interaction across the university. On the other hand, they lacked structural and financial support provided by the university, and faced problems with researchers feeling less membership in the centre when primary affiliation is with a department.

The use of the concepts multi-, inter-, cross- and transdisciplinarity also varied greatly on the websites, and these terms were sometimes used interchangeably, multi- and interdisciplinarity in particular. This was confirmed by the survey data. Interdisciplinarity was most often considered relatively loosely as the integration of various disciplines in the field of sustainability. Transdisciplinarity was most often understood as co-operation with external actors or bridging academia with society. Some centres understand it as a research service or communication for external stakeholders, others as an incorporation of non-academic knowledge in the research process during problem formulation or throughout the entire research process. One of the centres tried to apply a transdisciplinary approach, but found it too difficult due to the strong emphasis on quantitative work in environmental sustainability. Some respondents had a relatively open strategy in regards to inter- and transdisciplinarity, and left the definition along with the implementation of inter- and transdisciplinary approaches to individual researchers.

Only nine out of 44 centres were solely dedicated to research, whereas 35 centres also provided education at various levels, including Bachelor, Master and $\mathrm{PhD}$ programmes on sustainability, courses on sustainability issues and certification programmes. As for their engagement in sustainability science, 14 centres mentioned sustainability science on their website when presenting their research. Three of the centres used 'education in sustainability science' as the name of their Master or PhD studies. In most cases, the concept was not opened up or clarified on the website. In the survey, we asked how sustainability science is applied as a discipline in their work. Seven centres out of 16 reported that they used it as a connecting concept in their research, and many reported that it was the object of their research in broader terms (as a specific research topic of the centres) or used by individual researchers. The survey information also revealed that disagreements might have occurred concerning the use of the concept within the centre; some researchers were interested, while others were even hostile towards the whole idea.

The website analysis showed that all the centres incorporate outreach activities of at least one type (Figure 2 ). However, the diversity and intensity of outreach activities vary greatly between the centres. The most commonly practised type is the transfer of knowledge, i.e. the traditional task of universities. This is put into practice through public lectures, seminars, science days or forums and publications directed to the general public. Additionally, most of the centres are active in creating partnerships and collaboration with communities and partner organisations both locally and globally. The partner organisations of the studied centres range from foundations and government agencies to businesses, policymakers and activists. Outreach is used as a pedagogical approach in many centres: many of the co-operation projects with local communities are driven as student projects, and form an integrated part of the curricula of environmental/sustainability programmes. In addition, educating future sustainability researchers and experts, i.e. transformation agents, is clearly seen in the strong role of students centred on transdisciplinary actions. The survey responses further showed that the centres co-operate with NGOs, local communities, administration/policy and businesses. Most centres also promote the science-policy interface aiming at creating dialogue and joint actions with policymaking actors and institutions in various phases of research. A typical feature of sustainability science is also seen in the centres' strong commitment to promoting sustainable campus operations. 


\subsection{Typology for sustainability centres}

In the following, we briefly describe the main characteristics of the research approaches and activities applied by the centres (see also Table 3 and Figure 3). In brackets, we give examples of representative centres for each issue in question. Each centre is referred to as a number, and the key to the numbering is given in the supplementary material.

\section{Type I. "Sustaining development"}

Most centres of this type more or less follow the lines of sustainable development defined by Brundtland's report. We call these centres of sustaining development, as their focus is on safeguarding or ensuring sustainable development rather than trying to promote a change. They aim to foster sustainable futures through integrated research and learning about the linkages between human and natural systems by minimising the impact on the environment or by facilitating new approaches for responsible management $(10,18)$. Many centres express their mission as a need to address the threats to sustainability $(35)$. Other goals also exist, such as promoting sustainable growth (43) or prosperity (15). Transformation or social change is sometimes mentioned as a subtopic of the research themes (39), or they aim to explore steps to sustainability (15), but transformation is not mentioned as an overarching theme.

Despite a common spirit to ensure or safeguard sustainability in the changing conditions, the centres in this group are quite heterogeneous in terms of their research objects. They address the "pillars" of sustainability (social, economic, environmental) to various extent and contexts. Some focus solely on environmental $(3,20,22)$, social $(15)$ or economic and/or institutional $(25,43)$ aspects. The special focus of the research can be reflected by an overall strategy or emphasis of the university or institute they are associated with (social sciences, economics or environment) $(25,43)$.

The spatial scale of the research in most cases covers all the levels from individuals, to communities, companies, and the regional, national and global levels. A region can be used as a source/inspiration or "laboratory" for the research $(2,35)$, and in this way the centres are engaged in place-based development. Temporally most of the centres focus their research on the present, while highlighting the principles of sustainable development to ensure the needs of future generations.

These centres typically aim to facilitate a deeper understanding of connections between human and natural systems, their state or well-being. Although they might be engaged in participatory approaches, and mention interdisciplinarity or sustainability science as a topic, they often appear to apply disciplinary or multidisciplinary approaches in practice. A few centres may also be engaged in sustainability assessments (24). Although many of the centres have various activities with non-academic stakeholders, the knowledge produced is primarily meant to be "transferred" to society, or the centres consider themselves as having an advisory role in respect to society $(27,35)$. Some centres considered themselves as "hubs" of sustainability research, co-ordinating and gathering together sustainability research within the universities and for society. Community engagement is widely represented in these centres. Focus areas may cover various environmental and health aspects, for example, those connected to clean air and water. Working with communities aims to increase knowledge, support local appraisals and participatory planning.

\section{Type II. "Innovating technologically for sustainability"}

The goal of these centres is to promote environmental sustainability through technological innovations and solutions. Consequently, sustainability is typically seen as an environmental problem caused by climate change or limited natural resources: as a problem, it can be mitigated or solved with a new technology or approach. The aim is to find not only environmentally sound, but also economically feasible solutions for supporting the transition to sustainability. The underlying focus of these centres is more on practical solutions, either products or services and their impacts, than on fundamental systemic transformation. 
Such centres may have an idea of resilience or transition as a background or driver for their research, but

\section{Type III. "Building and maintaining resilience"}

Compared with type I centres, type III centres focus more on change. In particular, they are concerned with how systems cope with and adapt to change. Sustainability for these centres is not any state that has to be ensured, safeguarded or reached, but rather there is a need to find a certain balance (equilibrium, resilience). Consequently, this means that human activities and institutions along with the ecological systems should be (re)shaped to be able to respond to and manage change. Change is considered gradual, harmonious, linear and in line with the capacities of the people involved $(38,41)$.

Given their focus on the capability to adapt to change, such centres conduct their research on geographical contexts from local to global using a systemic approach integrating social, ecological and economic aspects, which distinguishes them from type I centres. These centres are particularly interested in interactions between society and nature, but compared to type I, they focus more on institutions and individuals when analysing conditions for adaptation and impacts of changing social and environmental conditions. This system or place can be a village, food chain or the entire planet, more or less strictly defined, but usually comprising of both ecological and social elements. Past development trajectories are taken into account, and design, redesign and planning becomes a part of the research activities, shifting focus from the present to the future (41).

Interdisciplinarity is a starting point for the research, and a variety of transdisciplinary participatory research methodologies and co-production approaches are used. Sustainability science is defined primarily through the resilience approach. Given the orientation towards transdisciplinary approaches, the centres do not only disseminate scientific knowledge, but also co-produce knowledge with various stakeholders. In this way, they aim not only to provide information, but also to involve stakeholders in the research process by using various participatory methods. The centres are characterised by performing research for policymaking with an emphasis on the co-production of knowledge.

Type IV. "Transforming society for sustainability" 
The centres belonging to this group have a strong focus on transition or transformation at a systemic level. about system innovations, i.e. processes of change that involve environmental, technical, economic and social dimensions. Understanding the dynamics of social-ecological systems serves as the basis for the research, but there is a strong ambition to go beyond understanding, and actually adapting towards changing them. Compared particularly to types I and II, these centres place more emphasis on humans as agents of change. Therefore, in their search for pathways to sustainability through human perceptions and values, they also acknowledge and explore the questions of power when defining and aiming for sustainability. The research may be performed at any temporal scale, but is usually oriented to the future, rather than the present or past.

Some centres have a strong inter/transdisciplinary research programme $(17,28,32,29,37)$; others are more ideologically committed to transformation without any systematic framework (36). Both qualitative and quantitative methods are brought together in transdisciplinary processes, along with dependency on the context and normative character of the sustainability, and in some cases, even a critical stance to sustainability and ethical dimensions is taken. Some of them aim to challenge conventional sustainability thinking and develop creative solutions to emerging issues of global concern in these areas $(32,37)$, while others focus on transformation within universities (42). Overall, these centres are action-oriented in their knowledge production, and use "living labs" for creating and testing knowledge (29). As an indication for their commitment to sustainability, centres of this type have a special research programme or team focusing on methodological and/or theoretical aspects of sustainability or sustainability science. Many of these centres focus on contributing to science-society dialogue, and students are given an active role in the outreach projects.

\section{Discussion}

\subsection{Evolvement and organisation of the sustainability centres}

The idea of establishing or having research centres or institutes within universities is not novel: generally, most universities we explored hosted various types of research centres or institutions. Yet, our study revealed that sustainability centres a) use the sustainability (development) concept as an overarching research framework, b) have a broad, problem-based and inter- and transdisciplinary focus, c) integrate natural and social sciences and the humanities, and d) place strong emphasis on societal impact and outreach. In these respect they are different from many other research centres. Such centres can function as a network of researchers with small administrative personnel or as independent units with their own headquarters and affiliated research and administrative personnel. Despite organisational, thematic or functional differences, such centres have a common aim to contribute to sustainability by applying multi, inter- or transdisciplinary approaches. Sustainability centres that conduct and co-ordinate sustainability education, research and outreach activities within the universities can have a crucial role in responding to the call for sustainability (Lozano et al. 2015) and they present the latest developments in a continuum of sustainable universities (Beynaghi et al. 2016).

Following Geels and Schot (2007) and Stephen and Graham (2010), we proposed that university-based sustainability centres can be seen as niches that share certain common characteristics (see Kemp et al. 1998). First, the centres were often initiated by individuals or small groups of people (see also and BakerShelley et al. 2017). Second, they were active in networking within the university. Internal networking can be derived from the broad scope of the sustainability research topics and interdisciplinary character of the research. It is obvious that by promoting inter- and transdisciplinary sustainability research and outreach, the centres also contribute to the missions and visions of universities as a whole (Beynaghi et al. 2016; 
Baker-Shelley et al. 2017) strengthening the institutionalisation of sustainability research and education (Yarime et al. 2012).

Sustainability centres give much attention to outreach activities and societal interaction engaging with local and regional actors and communities and promoting regional sustainability (Zilahy et al. 2009; Zilahy and Huisingh 2009). Yet, the study revealed that centres experience organisational barriers and missing structures when engaging with non-academic actors, and lack of funding (see also Genus \& Theobald 2015, Zilahy et al. 2009;). Here collaboration with other centres and research institutions can be found as an appealing opportunity explaining the popularity of various networks of the university around these activities (see Chapter 1.).

Our study provided a snapshot of the current state of the sustainability centres and their characteristics. However, we observed outside the actual research period evolvement of the organisational arrangement and scientific approaches even during the research process, and therefore argue that many of the centres are evolving rather than fixed institutions. Such an evolution can result from a need to meet rigid administrative structures and disciplinary-oriented research at the regime level or willingness to redirect their scientific focus while maintaining and developing their identities.

\subsection{Research themes and approaches responding to the sustainability aims}

Certain similarities can be found in the research themes across all the types: for example, global change, sustainable society, urban issues, food and energy were studied by each of the centre types. We assume that at the beginning, centres probably base their research on the current disciplines and expertise they have. Nearly all of the centres were formed around environmental sustainability, confirming that sustainability is still very much considered an environmental problem (Basset and Fogelman 2013). However, the focus of universities has been suggested to be increasingly shifting away from environmental aspects to other sustainability issues, i.e. integrating environmental, social and economic aspects (Beynaghi et al. 2016). Beynaghi et al. (2016) have also proposed that in the future universities will specialise in their sustainability orientation, focusing on environmental, social and economic aspects. In our study, the centres with a social and/or economic focus are in the minority. On the other hand, our study showed a strong interest in sustainability science, which does not support the idea of specialisation in environmental, social or economic aspects of sustainability, but rather defining and exploring the problems in a more holistic way.

Based on the research approaches in the sample, we were able to identify four different types of centres (Table 3). The types indicated various approaches to sustainability and change. In Figure 3, we have placed each typology in a quadrat comprised of two dimensions: the level of change and problem vs. solution orientation, which we identified as key aspects from the analytical framework (Chapter 2). Type I centres are most concerned with exploring the current state of sustainability, and measuring how sustainability is influenced by a change in environmental conditions (such as climate change). For these centres, sustainability represents a normative goal, following the principles of Brundtland's report, or the universalists (Miller 2014). They mainly focus on and exploring each problem rather than actively seeking for solutions and alternative pathways towards transformative change. Following Mustelin \& Handmer (2013), or in the words of Hopwood et al. (2005), their approach resembles "Status Quo", which recognises the need for change, but does not recognise that the environment or society are facing insuperable problems. In this view, adjustments can be made without any fundamental changes to society, means of decision-making or power relations. Consequently, type I centres consider themselves experts in the field of defining and exploring problems. 
For type II, sustainability challenges arise from above, and these centres develop practical solutions for with what Hopwood et al. (2005) call "Reformists". They may accept the existence of mounting problems, which are critical for the current policies of most businesses, governments and trends within society, but they do not necessarily consider a collapse in ecological or social systems as likely, nor that fundamental change is necessary. Here, technology is seen as a key means to facilitate change. They consider themselves (together with their stakeholders) as providers of solutions, taking a positivistic approach to knowledge production.

Sustainability is a dynamic state for type III centres, the balance of which is constantly changing and should be negotiated at the local/regional-place scale. Favourable pathways/strategies to maintaining balance should therefore be found at the systemic level. Yet, the focus is more on how to manage resilient change rather than actively seek ways or solutions to transform it, and in this way type III centres fall between "Status Quo" and "Reformist".

The definition of sustainability is left open for the last type of centres (IV), i.e. procedural (Miller 2014): sustainability is negotiated case by case. Centres of this type strongly emphasise the need for systemic change and actively seek solutions by means of transdisciplinary research and by exploring and demonstrating a multiplicity of various sustainability pathways. They admit that solutions are not as clear as they tend to be for type III centres, but rather complex, including a lot of uncertainty. According to Hopwood et al. (2005), "transformationists" agree that the transformation of society and/or human relations with the environment is necessary to avoid crises and even a possible future collapse. Reform is not enough. Consequently, more emphasis is placed on social equality, power issues and policymaking.

It has been argued that both incremental and transformational change proceeding towards sustainability is needed (Luederitz et al. 2017). On the other hand, Trencher et al. (2013) have noted that universities are co-existent and complementary in their missions and visions. Similarly, we insist that all types of centres have their role in the promotion of sustainability and that diverse approaches guarantee that various aspects of sustainability are well maintained. As universities have varying expertise and competences, we find it reasonable that they aim to contribute to the same goal - sustainability - with the strengths they have.

\section{Conclusions}

There is an increasing call for universities to contribute to societal needs, sustainability in particular. Our explorative study focused on sustainability centres, which have until now been neglected by research, but can make a critical contribution to sustainability. The study suggests that universities increasingly want to promote sustainability by establishing centres. These centres may gradually change the current regimes of the universities towards sustainability. We have confirmed that many of these sustainability centres belong to the latest developments in a continuum of sustainable universities (Beynaghi et al. 2016), and contribute to the institutionalisation of the sustainability research agenda. Yet, these centres are not yet mainstream activity within the current regime of the universities, and therefore they seek different strategies to meet organizational and scientific challenges. Although the centres face similar challenges in their establishment, there are numerous ways for solving these problems, as universities have unique organisational structures and cultures. In order to better understand how to facilitate sustainability integration in universities, we highly recommend further in-depth research to provide more thorough understanding of the establishment processes of the centres in different types of the universities (see also Baker-Shelley et al. (2017). The centres aim to co-ordinate sustainability research and activities within the universities. Further research is needed to find out what kind of leadership sustainability centres should take and how they should share responsibility and activities with other units. 
Our results give an overview of the main characteristics of these centres in various geographical contexts, and show the commonalities and differences between their organisation and scientific approaches. Overall, our observations are useful for understanding the position of these centres as niches within university structures, and their contribution to the sustainability transformation of universities. Given the complex and versatile character of the sustainability challenges and also various profiles of the universities mixing hard sciences, technological studies, social sciences, humanities and economics to various extent, we find the existence of a variety of scientific approaches within the centres important. Yet, research based on a large survey covering centres in Asia, South America and Africa would facilitate exact quantitative and geographical comparisons and better understanding of, for example, whether the distribution of the centres responding to various aspects of sustainability is sufficient and desirable in respect to the role of universities in sustainability. As our results suggest that almost all centres focus on environmental sustainability, we can assume that there is space for centres that consider social and cultural aspects not as means, but as a starting point for sustainability. Maybe this is the next future step in the emergence process of sustainability centres?

\section{Acknowledgements}

The authors wish to thank persons, who responded to the survey making the analysis possible, as well as gratefully acknowledge the editor and four anonymous reviewers for constructive feedback and valuable suggestions for the earlier versions of this paper. The research was funded by Helsinki University Centre for Environment, HENVI.

\section{List of references}

Adomssent, M. 2013. Exploring universities' transformative potential for sustainability-bound learning in changing landscapes of knowledge communication. Journal of Cleaner Production 49, 11-24.

Baker-Shelley, A.; Zeijl-Rozema, A., Martens, P. 2017. , A conceptual synthesis of organisational transformation: How to diagnose, and navigate, pathways for sustainability at universities? Journal of Cleaner Production 145: 262-276.

Barth, M., Michelsen, G. 2013. Learning for change: an educational contribution to sustainability science. Sustainability Science 8:103-119.

Basset, T.I., Fogelman, C. 2013. Déjà vu or something new? The adaptation concept in the climate change literature. Geoforum 48, 42-53.

Beynaghi, A., Trencher, G, Moztarzadeh, F., Mozafari, M. Maknoon, R., Leal Filho, W. 2016. Future sustainability scenarios for universities: moving beyond the United Nations Decade of Education for Sustainable Development. Journal of Cleaner Production 112, 1464-1474.

Chappin, E.J.L, Ligtvoet, A. 2014. Transition and transformation: A bibliometric analysis of two scientific networks researching socio-technical change. Renewable and Sustainable Energy Reviews 30, 715-723.

Dedeurwaerdere, T. 2013. Transdisciplinary sustainability science at higher education institutions: science policy tools for incremental institutional change. Sustainability 5, 3783-3801.

Feola, G. 2015. Societal transformation in response to global environmental change: A review of emerging concepts. Ambio 44, 376-390. 
Ferrer-Balas, D., Adachi, J., Banas, S., Davidson, C.I., Hoshikoshi, A., Mishra, A., Motodoa, Y., Onga, M., universities. International Journal of Sustainability in Higher Education, 9, 3, 295-316.

Ferrer-Balas, D., Buckland, H., de Mingo, M. 2009. Explorations on the University's role in society for sustainable development through a systems transition approach. Case-Study of the Technical University of Catalonia (UPC). Journal of Cleaner Production 17, 1075-1085.

Ferrer-Balas, D., Lozano, R., Hisingh, D., Buckland, H., Ysern, P., Zilahy, G. 2010. Going beyond the rhetoric: system-wide changes in universities for sustainable societies. Journal of Cleaner Production 18, 607-610.

Geels, F.W. 2002. Technological transitions as evolutionary reconfiguration processes: a multi-level perspective and a case-study. Research Policy 31: 1257-1274.

Geels, F. W., Schot, J. 2007. Typology of sociotechnical transition pathways. Research Policy 36: 399417.

Genus, A., Theobald, K. 2015. Roles for university researchers in urban sustainability initiatives: the UK Newcastle Low Carbon Neighbourhoods project. Journal of Cleaner Production -106: 119-126.

Hopwood, B., Mellor, M., O’Brien, G. 2005. Sustainable Development: Mapping Different Approaches. Sustainable Development 13, 38-52.

Hsieh, H. F., Shannon, S. E. 2005.Three approaches to qualitative content analysis. Qualitative health research $15,9,1277-1288$.

Huge, J., Block, T., Waas, T., Wright, T., Dahdouh-Guebas 2016. How to walk the talk? Developing actions for sustainability in academic research. Journal of Cleaner Production 137, 83-92.

Kates et al. 2001. Sustainability Science. Science 292, 5517, 641-642.

Kemp, R., Schot, J., Hoogma, R. 1998. Regime shifts to sustainability through processes of niche formation: the approach of strategic niche management. Technology Analysis and Strategic Management 10, 175-196.

Kluge, S. 2000. Empirically Grounded Construction of Types and Typologies in Qualitative Social Research. Qualitative Social Research 1(1), Art. 14 . available at http://www.qualitativeresearch.net/index.php/fqs/article/viewArticle/1124/2499

König, A. 2015. Changing requisites to universities in the 21st century: organizing for transformative sustainability science for systemic change. Current Opinion in Environmental Sustainability 16,105-111.

Kueffer, C., Underwood, U., Hirsch Hadorn, G., Holderegger, R., Lehning, M., Pohl, C., Schirmer, M., Schwarzenbach, R., Stauffacher, M., Wuelser, G., Edwards, P. 2012. Enabling effective problemoriented research for sustainable development. Ecology and Society 17, 4, 8

Lonsdale, K., Prinle, P., Turner, B. 2015. Transformative adaptation: what it is, why it matters \& what is needed. UK Climate Impact Programme, University of Oxford, UK.

Lozano, R., Ceulemans, K., Alonso-Almeida, M., Huisingh, D., Lozano, F.J., Waas, T., Lambrechts, W., Lukman, R., Huge, J. 2015. A review of commitment and implementation of sustainable development in higher education: results from a worldwide survey. Journal of Cleaner Production 108, 1-18. 
Lotz-Sisitka, H., Wals, A.E.J., Kronlid, D., McGarry, D., 2015. Transformative, transgressive social learning: rethinking higher education pedagogy in times of systemic global dysfunction. Current Opinion in Environmental Sustainability 16:73-80

Luederitz, D., Abson, D., Audet, R., Lang, D. Many pathways toward sustainability: not conflict but colearning between transition narratives. Sustain Sci 12: 393-407.

Markard, J., Raven, R., Truffer, B. 2012. Sustainability transitions: An emerging field of research and its prospects. Research Policy 41: 955-967.

Mezirow, J. 1995. Transformation Theory of Adult Learning. In Welton, M.R. (ed.) In Defense of the Lifeworld. New York: SUNY Press, pp. 39-70.

Miller T. R. 2014. Reconstructing sustainability science. Knowledge and Action for a Sustainable Future. Science in Society Series. Earthscan, Routledge.

Mustelin, J. and Handmer, J. 2013. Triggering transformation: Managing resilience or invoking real change? Proceedings in Transformation in Changing Climate, Oslo 2013. 24-32.

Nowotny, H., Scott, P., Gibbons, M. 2001. Re-Thinking Science, Knowledge and the Public in an Age of Uncertainty. Cambridge: Polity.

Poteete, A., Janssen, M.A., Ostrom, E. 2010. Working Together: Collective Action, the Commons, and Multiple Methods in Practice. Princeton University Press. Redman, C.L. 2014. Should sustainability and resilience be combined or remain distinct pursuits. Ecology and Society 19 (2): 37.

Schulz, K. and Siriwardane, R. 2015. Depoliticized and Technocratic? Normativity and the Politics of Transformative Adaptation. Earth System Governance Working Paper No. 33. Earth System Governance Project, Lund and Amsterdam.Shils, E. and Finch, H. (trans. and ed.), The methodology of the social sciences (1903-17). New York: Free Press, p. 90.

Soini, K. 2017. Kestävyystiede - kestävän kehityksen uusi paradigma? [Sustainability Science - A New Paradigm of Sustainability?]. Tieteessä tapahtuu 1/2017. In print. [In Finnish].

Spangenberg, J. 2011. Sustainability science: a review, an analysis and some empirical lessons. Environmental Conservation 38 (3): 275-287.

Stephen, C., Graham, A.C. 2010. Toward an empirical research agenda for sustainability in higher education: exploring the transition management framework. Journal of Cleaner Production 18, 611618.

Sterling, S. 2010. Learning for resilience, or the resilient learner? Towards a necessary reconciliation in a paradigm of sustainable education. Environmental Education Research 16, 5-6: 511-528. Stirling, A. 2014. Emancipating Transformations: From controlling 'the transition' to culturing plural radical progress. STEPS Working papers $64.41 \mathrm{p}$.

Trencher, G., Yarime, M., McCormick, K.B., Doll, C.N.H., Kraines, S.B. 2013. Beyond the third mission: Exploring the emerging university function of co-creation for sustainability. Science and Public Policy, 129.

Trencher, G., Bai, X., Evans, J., McCormick, K., Yarime, M. 2014a. University partnerships for codesigning and co-producing urban sustainability. Global Environmental Change 28 (2014) 153-165 
Trencher, G., Yarime, M., Kharrazzi, A. 2014b. Co-creating sustainability: cross-sector university collaborations for driving sustainable urban transformations. Journal of Cleaner Production 50, 40-55.

Waas, T., Verbruggen, A., Wright, T. 2010. University research for sustainable development: definition and characteristics explored. Journal of Cleaner Production 18, 7, 629-636.

Wiek, A., Farioli, F., Fukushi, K., Yarime, M. 2012. Sustainability science: bridging the gap between science and society. Sustainability Science 7, Supplement 1, 1-4.

Wiek, A., Lang, D. J. 2016: Transformational Sustainability Research Methodology. In: Heinrichs, H.; Martens, P.; Michelsen, G.; Wiek, A. (eds.): Sustainability Science: An Introduction. Springer: Dordrecht u.a.. p. 31-41.

Will, M. \& Ryden, L. 2015. Integrative Approaches to Sustainable Development at University Level Making the Links. In Filho, L.W., Brandli, L, Kuznetsova, O., Paco, A.M.F.d. (eds). Integrative pproaches to Sustainable Development at University level. Springer.

Zilahy, G., Huisingh, D., Melanen, M., Phillips, V.D., Sheffy, J. 2009. Roles of academia in regional sustainability initiatives: outreach for a more sustainable future. Journal of Cleaner Production 17: 1053-1056.

Zilahy and Huisingh 2009. The roles of academia in Regional Sustainability Initiative. Journal of Cleaner Production 17: 1057-1066.

Yarime, M., Trencher, G., Mino, T., Scolz, R.W., Olsson, L., Ness, B., Frantzeskaki, N., Rotmans, J. 2012. Establishing sustainability science in higher education institutions: towards an integration of academic development,institutionalization, and stakeholder collaborations. Sustain Sci 7: 101-113. 
Table 1. Datasets used in the study.

\begin{tabular}{|c|c|c|}
\hline Dataset & Questions & Purpose and use \\
\hline $\begin{array}{l}\text { Website } \\
\text { content }\end{array}$ & $\begin{array}{l}\text { Open input categories concerning: } \\
\text { - Location; } \\
\text { - Organisational structure } \\
\text { (network of researchers; } \\
\text { independent unit; other); } \\
\text { - Goal, research topic and } \\
\text { fields; } \\
\text { - Centre's background; } \\
\text { - Staff (research and } \\
\text { - } \text { administrative); } \\
\text { - } \text { History; } \\
\text { - Interation; } \\
\text { Interaction with society and } \\
\text { outreach }\end{array}$ & $\begin{array}{l}\text { The data were gathered to explore various } \\
\text { university-based sustainability centres and } \\
\text { their main characteristics. The data were used } \\
\text { to conduct descriptive analysis (see Section } \\
\text { 4.1.Table 2) and qualitative content analysis of } \\
\text { the centres' approaches, based on which we } \\
\text { proposed the Typology (Section 4.2.; Table 3) }\end{array}$ \\
\hline Survey & $\begin{array}{l}\text { Structured and open questions } \\
\text { concerning: } \\
\text { - } \quad \text { Organisational structure; } \\
\text { - } \text { Advantages and disadvantages } \\
\text { of positioning; } \\
\text { - } \quad \text { Main task; } \\
\text { - } \quad \text { Staff; } \\
\text { - } \quad \text { Funding sources; } \\
\text { - } \text { How centre was established; } \\
\text { - } \quad \text { Factors enabling and } \\
\text { hindering the establishment; } \\
\text { - Challenges during its } \\
\text { existence; } \\
\text { Role of Sustainability Science; } \\
\text { - Incorporation of inter- and } \\
\text { transdisciplinarity; } \\
\text { - Outreach; } \\
\text { - Future development }\end{array}$ & $\begin{array}{l}\text { The data were gathered and used for in-depth } \\
\text { analysis of the centres' establishment; } \\
\text { enabling and hindering factors; inter- and } \\
\text { transdisciplinarity; role of sustainability } \\
\text { science. }\end{array}$ \\
\hline
\end{tabular}


Table 2. Main characteristics of the studied 44 centres.

\begin{tabular}{|c|c|c|c|c|c|c|c|c|c|}
\hline Location & & Organisation & & Established & & Education /resear & & Staff & \\
\hline $\begin{array}{l}\text { UK } \\
\text { USA } \\
\text { Germany } \\
\text { Sweden } \\
\text { Netherlands } \\
\text { Canada } \\
\text { Belgium } \\
\text { Austria } \\
\text { Switzerland } \\
\text { Denmark } \\
\text { New Zealand } \\
\text { Japan } \\
\text { International }\end{array}$ & $\begin{array}{l}12 \\
12 \\
5 \\
3 \\
3 \\
2 \\
1 \\
1 \\
1 \\
1 \\
1 \\
1 \\
1\end{array}$ & $\begin{array}{l}\text { Independent } \\
\text { unit } \\
\text { Network } \\
\text { Consortium }\end{array}$ & $\begin{array}{l}28 \\
14 \\
2\end{array}$ & $\begin{array}{l}\text { before } 1999 \\
2000-2005 \\
2006-2010 \\
2011-2016\end{array}$ & $\begin{array}{l}3 \\
10 \\
16 \\
15\end{array}$ & $\begin{array}{l}\text { Education and } \\
\text { research } \\
\text { Research only }\end{array}$ & $\begin{array}{l}35 \\
9\end{array}$ & $\begin{array}{l}\geq 100 \\
30-50 \\
10-20 \\
\geq 10 \\
N^{1}\end{array}$ & $\begin{array}{l}3 \\
6 \\
8 \\
8 \\
20\end{array}$ \\
\hline
\end{tabular}

\footnotetext{
${ }^{1}$ Nearly half (20) of the websites did not present information on the number of research and/or administrative personnel.
} 
Table 3. Typology for sustainability centres.

\begin{tabular}{|c|c|c|c|c|}
\hline & $\begin{array}{l}\text { Type I. } \\
\text { Sustaining } \\
\text { development }\end{array}$ & $\begin{array}{l}\text { Type II. } \\
\text { Innovating } \\
\text { technologically for } \\
\text { sustainability }\end{array}$ & $\begin{array}{l}\text { Type III. } \\
\text { Building and } \\
\text { maintaining } \\
\text { resilience }\end{array}$ & $\begin{array}{l}\text { Type IV. } \\
\text { Transforming } \\
\text { society for } \\
\text { sustainability }\end{array}$ \\
\hline \multicolumn{5}{|l|}{ Goal } \\
\hline $\begin{array}{l}\text { Goal in respect } \\
\text { to sustainability }\end{array}$ & $\begin{array}{l}\text { ensure or safeguard } \\
\text { sustainability; to } \\
\text { address threats to } \\
\text { sustainability }\end{array}$ & $\begin{array}{l}\text { transition to } \\
\text { sustainability } \\
\text { through } \\
\text { technological } \\
\text { innovations }\end{array}$ & $\begin{array}{l}\text { capability to adapt; } \\
\text { sustainability is } \\
\text { equal to resilience }\end{array}$ & $\begin{array}{l}\text { social, systemic } \\
\text { change towards } \\
\text { sustainability }\end{array}$ \\
\hline \multicolumn{5}{|l|}{$\begin{array}{l}\text { Object and } \\
\text { scale }\end{array}$} \\
\hline $\begin{array}{l}\text { Object of } \\
\text { research }\end{array}$ & $\begin{array}{l}\text { environmental, } \\
\text { economic and/or social } \\
\text { pillar of sustainability } \\
\text { in a variety of contexts: } \\
\text { livelihoods, well-being, } \\
\text { nature conservation; } \\
\text { improvement of } \\
\text { (environmental) } \\
\text { management and } \\
\text { nature conservation } \\
\text { practices }\end{array}$ & $\begin{array}{l}\text { societal practices, } \\
\text { technologies; mostly } \\
\text { (but not exclusively) }\end{array}$ & $\begin{array}{l}\text { social-ecological } \\
\text { systems and places } \\
\text { at various scales; } \\
\text { resilience and } \\
\text { adaptation; } \\
\text { policy and } \\
\text { governance }\end{array}$ & $\begin{array}{l}\text { transformation of } \\
\text { the systems or } \\
\text { subsystems }\end{array}$ \\
\hline Temporal focus & present & future & $\begin{array}{l}\text { past - present - } \\
\text { future }\end{array}$ & $\begin{array}{l}\text { past - present - } \\
\text { future }\end{array}$ \\
\hline $\begin{array}{l}\text { Research } \\
\text { themes }\end{array}$ & $\begin{array}{l}\text { sustainable societies; } \\
\text { global change, } \\
\text { governance \& } \\
\text { transition; sustainable } \\
\text { food, water and } \\
\text { agriculture; } \\
\text { biodiversity \& ecology; } \\
\text { climate change. }\end{array}$ & $\begin{array}{l}\text { urban research and } \\
\text { housing; energy; } \\
\text { technologies \& } \\
\text { innovations; } \\
\text { economy; materials } \\
\text { \& resources. }\end{array}$ & $\begin{array}{l}\text { sustainable } \\
\text { societies; global } \\
\text { change, } \\
\text { governance \& } \\
\text { transition; } \\
\text { sustainable food, } \\
\text { water \& } \\
\text { agriculture; urban } \\
\text { research; economy; } \\
\text { human well-being } \\
\text { \& health. }\end{array}$ & $\begin{array}{l}\text { global change, } \\
\text { governance \& } \\
\text { transition; } \\
\text { sustainable } \\
\text { societies; } \\
\text { sustainability } \\
\text { science; human } \\
\text { well-being \& } \\
\text { health; economy; } \\
\text { energy; } \\
\text { technologies and } \\
\text { innovations. }\end{array}$ \\
\hline \multicolumn{5}{|l|}{$\begin{array}{l}\text { Type of } \\
\text { knowledge }\end{array}$} \\
\hline $\begin{array}{l}\text { Type of } \\
\text { knowledge }\end{array}$ & $\begin{array}{l}\text { understanding, } \\
\text { assessing, monitoring, } \\
\text { modelling }\end{array}$ & $\begin{array}{l}\text { solution-oriented } \\
\text { knowledge }\end{array}$ & $\begin{array}{l}\text { systemic } \\
\text { knowledge, } \\
\text { planning, } \\
\text { understanding } \\
\text { dynamic } \\
\text { interactions }\end{array}$ & $\begin{array}{l}\text { transformative } \\
\text { knowledge }\end{array}$ \\
\hline
\end{tabular}




\begin{tabular}{|c|c|c|c|c|}
\hline $\begin{array}{l}\text { Sustainability } \\
\text { science }\end{array}$ & not used as a concept & not used as a concept & $\begin{array}{l}\text { used as a concept } \\
\text { in research, but } \\
\text { applied in the } \\
\text { resilience context }\end{array}$ & $\begin{array}{l}\text { used as an } \\
\text { overarching } \\
\text { concept in research } \\
\text { and education }\end{array}$ \\
\hline \multicolumn{5}{|l|}{$\begin{array}{l}\text { Methodologies } \\
\text { and actions }\end{array}$} \\
\hline Methodologies & $\begin{array}{l}\text { primarily } \\
\text { multi/interdisciplinary }\end{array}$ & $\begin{array}{l}\text { monodisciplinary/ } \\
\text { engineering, } \\
\text { multidisciplinary, } \\
\text { transdisciplinary }\end{array}$ & $\begin{array}{l}\text { inter/transdiscipli- } \\
\text { nary }\end{array}$ & transdisciplinary \\
\hline $\begin{array}{l}\text { Role in respect } \\
\text { to policymaking } \\
\text { /society }\end{array}$ & $\begin{array}{l}\text { advice, support, policy } \\
\text { analysis }\end{array}$ & $\begin{array}{l}\text { providing technical } \\
\text { and practical } \\
\text { innovations and } \\
\text { solutions, co- } \\
\text { production of } \\
\text { knowledge with } \\
\text { industry }\end{array}$ & $\begin{array}{l}\text { understanding } \\
\text { policymaking and } \\
\text { its impact; } \\
\text { influence } \\
\text { policymaking } \\
\text { through } \\
\text { participation and } \\
\text { co-production }\end{array}$ & $\begin{array}{l}\text { co-production of } \\
\text { knowledge with the } \\
\text { policymaking } \\
\text { bodies }\end{array}$ \\
\hline $\begin{array}{l}\text { Outreach } \\
\text { objectives and } \\
\text { ways to } \\
\text { implement }\end{array}$ & $\begin{array}{l}\text { community and } \\
\text { campus engagement } \\
\text { and multi-stakeholder } \\
\text { co-operation to } \\
\text { support in } \\
\text { stakeholders' quest for } \\
\text { sustainable } \\
\text { development }\end{array}$ & $\begin{array}{l}\text { create partnerships } \\
\text { to make a difference } \\
\text { and find (technical) } \\
\text { solutions }\end{array}$ & $\begin{array}{l}\text { research and } \\
\text { dissemination of } \\
\text { knowledge for } \\
\text { evidence-based } \\
\text { policymaking }\end{array}$ & $\begin{array}{l}\text { activities to } \\
\text { promote social } \\
\text { impact towards } \\
\text { sustainability and } \\
\text { integration of } \\
\text { sustainability } \\
\text { coherently to } \\
\text { universities }\end{array}$ \\
\hline $\begin{array}{l}\text { Representative } \\
\text { example of the } \\
\text { type of the } \\
\text { centre }\end{array}$ & $\begin{array}{l}\text { Atkinson Center for a } \\
\text { Sustainable Future, } \\
\text { Cornell University, US }\end{array}$ & $\begin{array}{l}\text { Duke Center for } \\
\text { Sustainability \& } \\
\text { Commerce, Duke } \\
\text { University, US }\end{array}$ & $\begin{array}{l}\text { Sustainable Places } \\
\text { Research Institute, } \\
\text { Cardiff University, } \\
\text { UK }\end{array}$ & $\begin{array}{l}\text { STEPS Centre, } \\
\text { University of } \\
\text { Sussex, UK }\end{array}$ \\
\hline
\end{tabular}




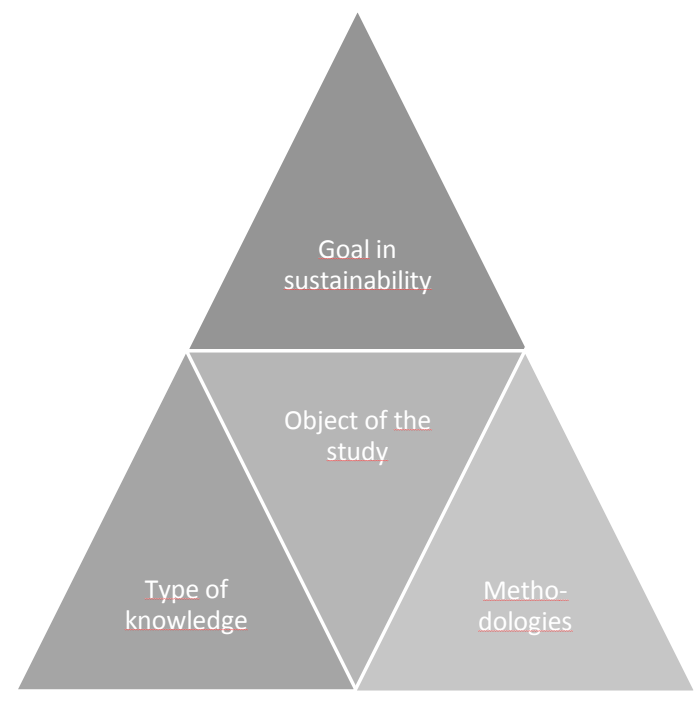

Figure 1. The scientific approaches employed by the centres may reflect differences in the object of the study, goal in sustainability, type of knowledge and methodologies used. (Adapted from Soini 2017). 


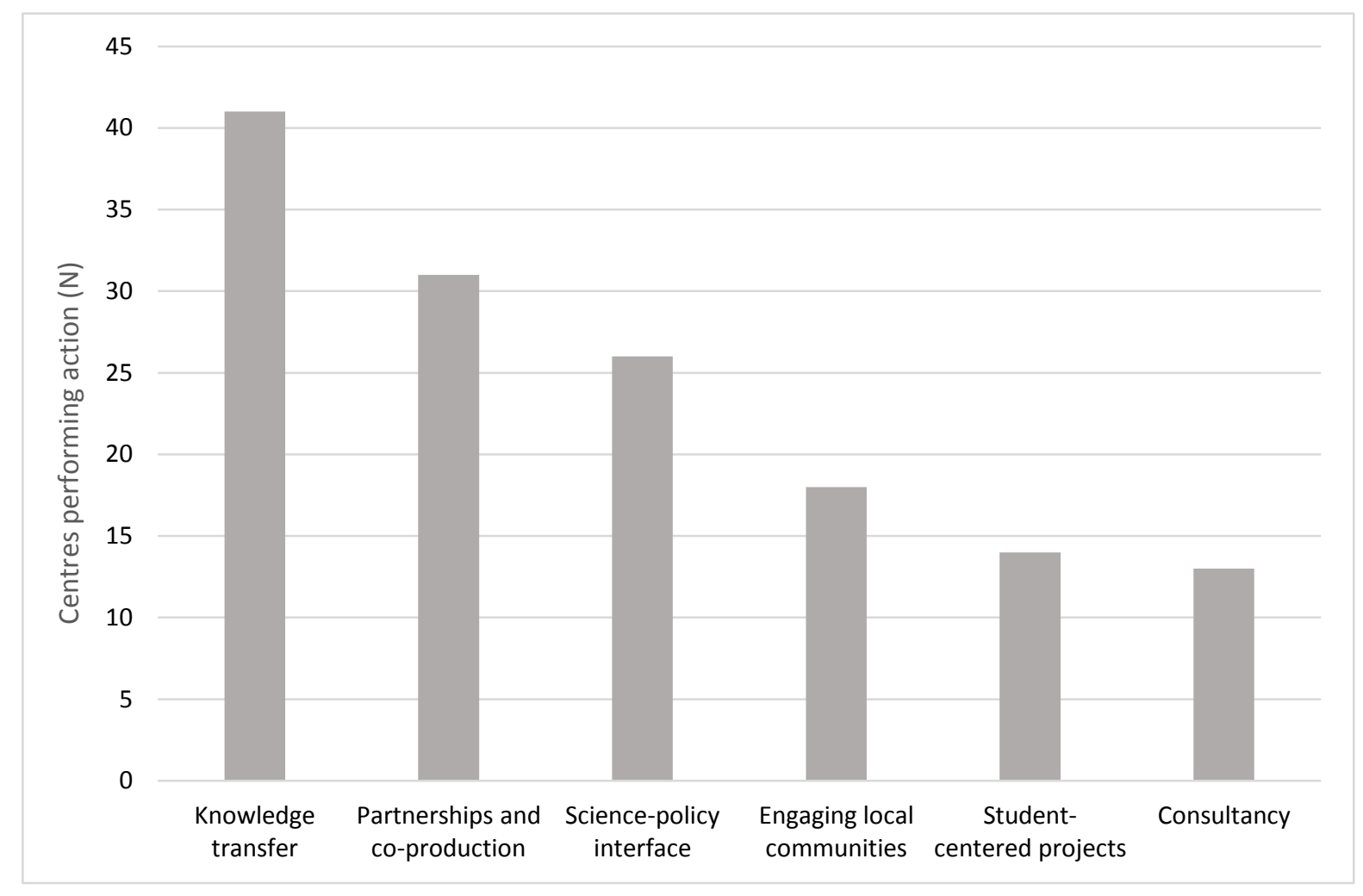

Figure 2. Outreach activities as presented by the centres on their public domains (44 in total). 


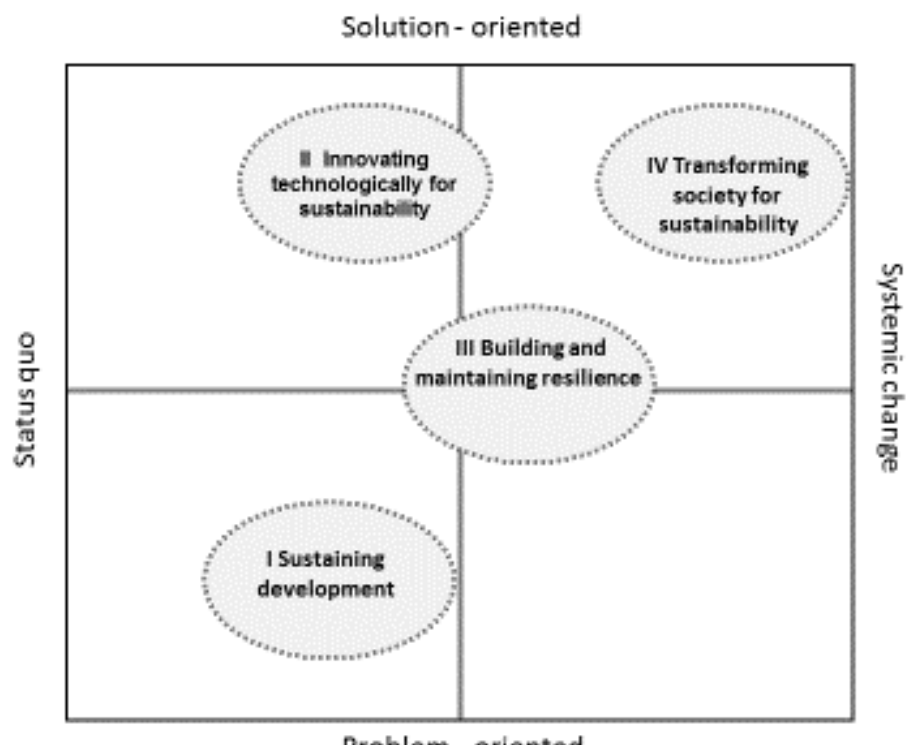

Problem - oriented

Figure 3. The four types of centres illustrated in a quadrat comprised of two dimensions: level of change and problem vs. solution orientation. 